\title{
Fístula arteriovenosa del labio inferior. Presentación de un caso
}

\author{
Arteriovenous fistula of the lower lip. Case report
}

\author{
M. Estrada Sarmiento ${ }^{1}$, L.I. Virreyes Espinosa², S. Gonzáles Pardo3
}

\begin{abstract}
Resumen: El objetivo del trabajo es exponer nuestra experiencia en el tratamiento quirúrgico de una fístula arteriovenosa del labio inferior de una paciente de 15 años de edad, producida por un mordisco. La paciente fue diagnosticada en su inicio como un hemangioma traumático, el cual fue tratado con esteroides y exéresis quirúrgica. A los 4 años apareció con una tumoración más voluminosa, se realizó disección de la carótida externa y arteriografía carotídea la cual diagnóstico fístula arteriovenosa, se realizó ligadura de la facial y de los vasos venosos, para aislarla de la circulación. Se inyectaron $4 \mathrm{cc}$ de betametazona en la tumoración, posteriormente se inyectaron 4 inyecciones adicionales con intervalos e 3 semanas, a los tres meses de la ligadura de los vasos sé realizo la exéresis de la fibrosis de la tumoración. En estos momentos la paciente tiene 5 años desde la última intervención, no presentando recidiva. Se destaca la importancia del estudio angiográfico para el diagnóstico y tratamiento de esta entidad patológica, que es poco frecuente.
\end{abstract}

Palabras clave: Fístula arteriovenosa; Angioma; Malformación vascular

Recibido: 01.06 .05

Aceptado: 06.10 .06

\begin{abstract}
The object of this work is to present our experience in the surgical management of an arteriovenous fistula in the lower lip of a fifteen year-old patient as a result of a bite. The patient was diagnosed initially as having a trauma-induced hemangioma, which was treated with steroid and surgical exeresis. Four years later, a larger tumor appeared. The external carotid artery was dissected and an arteriography of the carotid was carried out that gave the diagnosis of arteriovenous fistula. Ligation was carried out of the facial artery and of the venous vessels for isolation from the circulation. Four injections were given with $4 \mathrm{cc}$ of betamethasone into the mass. Later 4 additional injections were given with intervals of 3 weeks. Four months after the ligation of the vessels, the fibrous mass was excised. Five years have now passed since the last intervention and there has been no recurrence. The importance of the angiography should be highlighted for diagnosing and treating this very rare pathological entity.
\end{abstract}

Key words: Arteriovenous fistula; Angioma; Vascular malformation

1 Profesor auxiliar. Especialista de II grado Cirugía Maxilo Facial. Presidente de la Filiar Granma de Cirugía Maxilo Facial. Asesor de la Universidad Virtual de Salud.

2 Licenciada en enfermería Jefa del área quirúrgica.

3 Especialista de I grado en anestesia y reanimación. Vice director quirúrgico.

Granma, Cuba

\section{Correspondencia:}

Manuel Estrada Sarmiento

Máximo Gómez 6 / maceo y Canducha Figueredo.

Bayamo CP: 85100 Granma, Cuba

Email: mesarmiento.grm@infomed.sld.cu 


\section{Introducción}

Se conoce como fístula arteriovenosa, la comunicación anormal entre una arteria y una vena.

Puede ser congénita o adquirida. ${ }^{1}$ Las de tipo congénito son extremadamente raras. El 50\% radican en el ámbito de la cabeza y del cuello; la forma adquirida es producida por un traumatismo que ocasiona la rotura de los vasos sanguíneos. Al producirse la cicatrización una arteria se comunica con una vena y se invierte el flujo normal de la sangre. A causa del aumento de la presión sanguínea en la zona afectada, los vasos se dilatan y pueden semejar un hemangioma cavernoso o un aneurisma. ${ }^{1-3}$ Esta lesión ha sido un reto al tratamiento, presentando no solo un problema técnico a su resección quirúrgica, sino también a la restauración anatómica y funcional del área afectada. ${ }^{4}$ Cuando se operan se han de resecar extensamente o las posibilidades de recidiva son muy altas, ya que se crea una circulación colateral muy amplia que empeora el cuadro. ${ }^{4}$

Las fístulas arteriovenosas del labio inferior de origen traumático son poco frecuentes. En la literatura médica revisada solo hemos encontrado un caso publicado en Cuba por Felipe Rodríguez, ${ }^{1}$ similar al nuestro.

Lo poco habitual de esta afección nos motivó a revisar la literatura y exponer este trabajo que se basa en nuestra experiencia adquirida durante 9 años en una paciente portadora de esta entidad patológica.

\section{Características clínicas}

Los síntomas locales son:

- Soplo.

- Thrill.

- Flebectasia.

- Hipertemia.

Diagnóstico. Debemos pensar en una fístula arteriovenosa siempre que aparezca soplo y thrill en una región en la cual se ha producido una herida penetrante.

Diagnóstico diferencial. La fístula arteriovenosa debe diferenciarse de:

- Malformaciones venosas. Es una masa blanda, compresible pulsátil. Estas lesiones crecen proporcionalmente con el paciente y frente. B) Vista lateral.
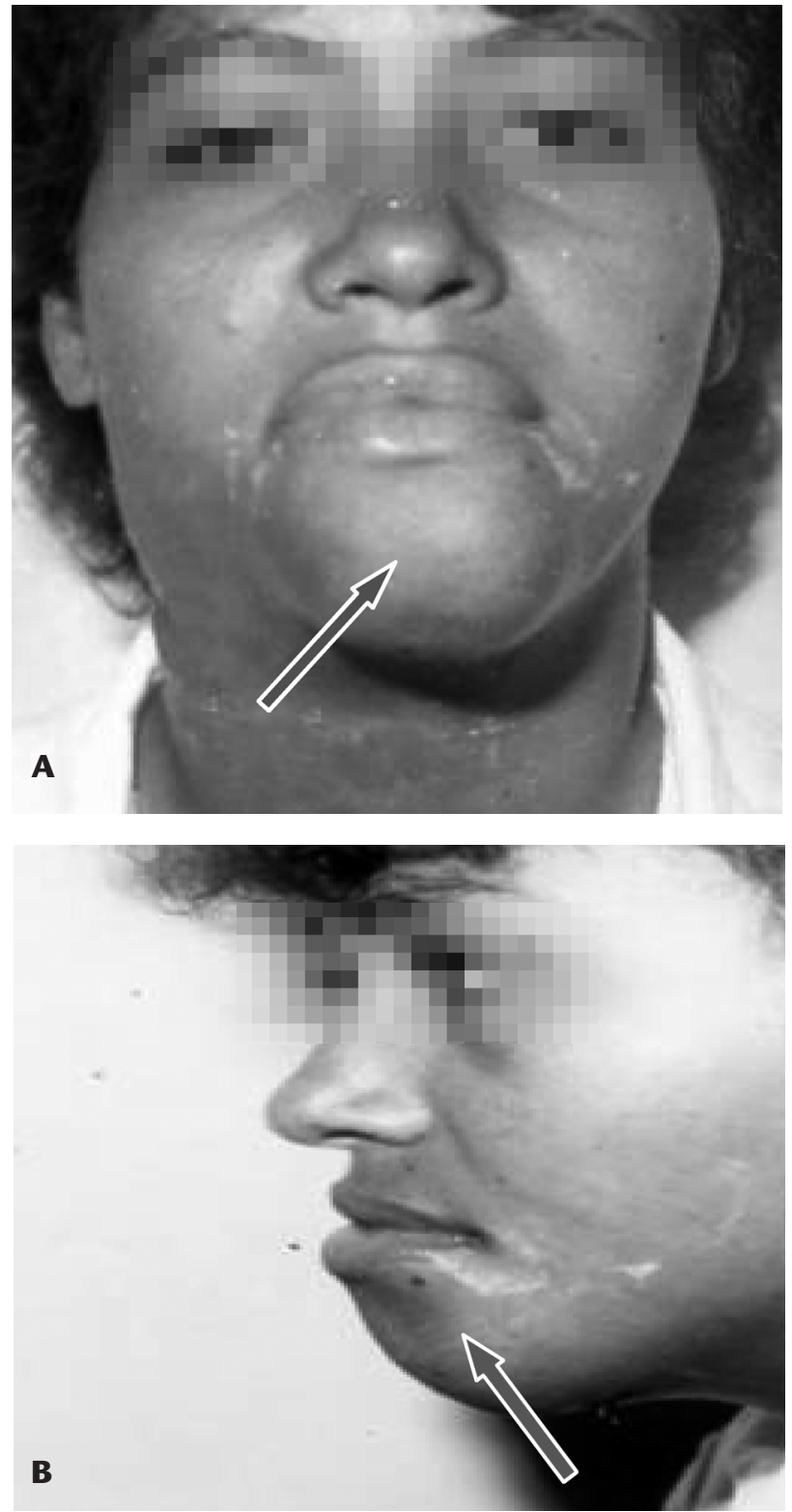

Figura 1. Aumento de volumen de región labial y mentoniana que ocasiona deformidad del tercio inferior de la cara. A) Vista de

Figure 1. Increase in the volume in lip and chin area causing deformity of the lower third of the face. A) Face-on view. B) Side-on view. Rodríguez that is similar to ours. The rarity of this condition motivated us to review the literature and produce this work based on the experience acquired over nine years with a patient with this pathological entity.

\section{Clinical characteristics}

The local symptoms are:

- Murmur.

- Thrill.

- Phlebectasia.

- Hyperthemia.

An arteriovenous fistula is an abnormal communication between an artery and $a$ vein. It can be congenital or acquired. ${ }^{1}$ Those that are congenital are extremely rare and $50 \%$ occur in the area of the head and neck. The acquired form is produced by trauma leading to broken blood vessels. On healing, an artery communicates with a vein and the normal blood flow is inverted. As a result of an increase in blood pressure in the affected area, the vessels dilate appearing to be a cavernous hemangioma or an aneurisma.1,3 This lesion has been a challenge with regard to treatment, as its surgical removal is a technical problem, as is the anatomic restoration and function of the area affected. ${ }^{4}$ When operated it has to be extensively resected or the possibilities of recurrence are very high, as collateral circulation is created that is very ample, and this worsens the symptoms. ${ }^{4}$

Trauma-induced arteriovenous fistulas of the lower lip are very rare. In the medical literature reviewed, we have only found one case published in Cuba b 
aumentan al comprimir la vena yugular o con la maniobra de Valsaba.

- Malformaciones linfáticas. Son congénitas y muchas son vistas al nacimiento.

- Hemangiomas. Son tumoraciones vasculares con fase de crecimiento marcado por proliferación endoterial y celular y una fase de involución.

\section{Caso clínico}

Paciente RGP, HC: 681458 del sexo femenino, que tiene como motivo de ingreso un aumento del volumen del labio inferior.

La historia de la enfermedad se remonta a la edad de 15 años cuando la paciente recibió un mordisco en el labio inferior con una intensa hemorragia. A partir del traumatismo apareció en la región central y derecha del labio un aumento progresivo, indoloro, de color azul violáceo, pulsátil, de $3 \mathrm{~cm}$ de diámetro. Clasificada la lesión como hemangioma traumático, se comenzó a tratar con inyecciones de betametasona. Luego de 6 dosis con betametasona, se realizó la exéresis de la tumoración por vía bucal. El diagnóstico histopatológico fue compatible con hemangioma traumático.

A los dos años de este tratamiento la paciente nos consulta nuevamente, ya que presentaba un aumento de volumen labial inferior más voluminoso, pulsátil, con soplo y frenito (Fig. 1). Al examen intrabucal se observan los relieves vasculares en la mucosa del labio inferior (Fig. 2) Indicamos ecografía de la región y ejecutamos una disección de la carótida derecha para arteriografía la cual informa de un saco aneurismático a nivel de las regiones labial inferior $y$ mentoniana (Figs. 3 y 4).

Se ligó la arteria carótida externa entre la tiroidea superior y la lingual (Fig. 5), por incisión submentoniana se ligaron los vasos venosos del aneurisma, para aislar esta cavidad de la circulación.

Al final de la intervención quirúrgica se inyectaron $4 \mathrm{cc}$ de betametasona en la tumoración y se aplicó un esparadrapo elástico.

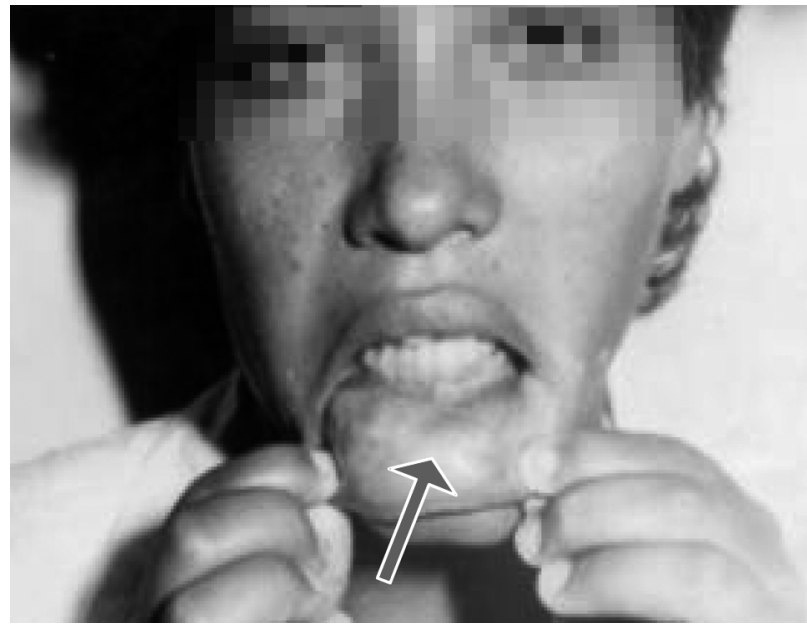

Figura 2. Vista intrabucal de la tumoración donde se observan los relieves vasculares.

Figure 2. Intra-buccal view of mass showing raised vascular pattern.

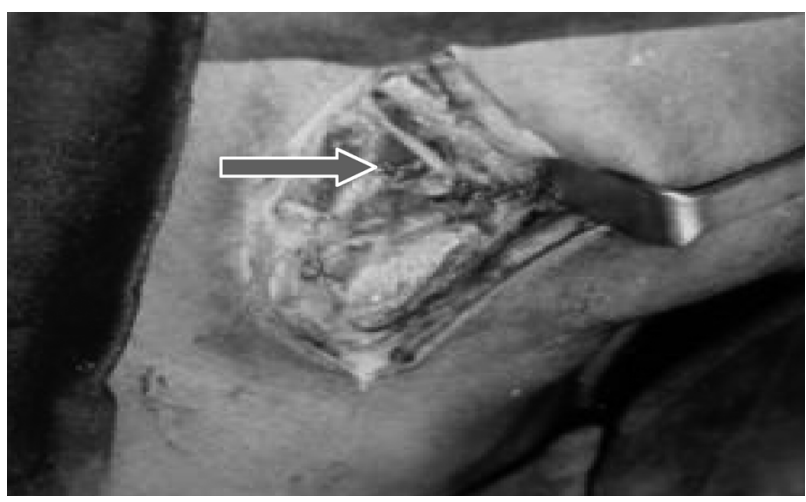

Figura 3. Disección de las carótidas primitivas y externa.

Figure 3. Dissection of the primitive and external carotid arteries.

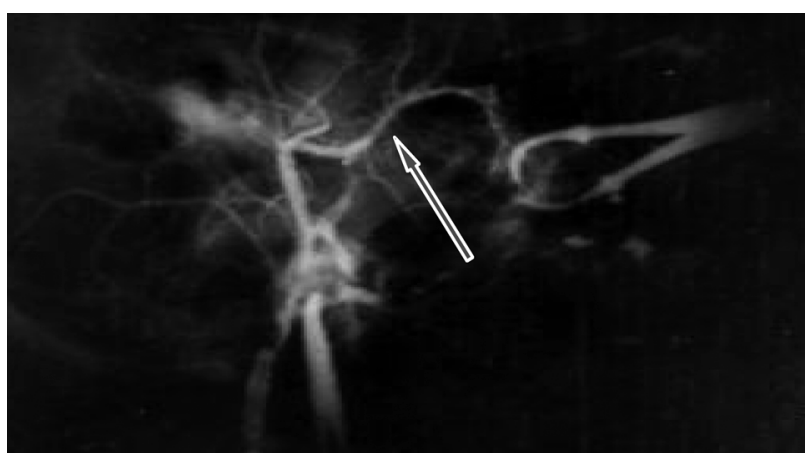

Figura 4. Arteriografía carotídea externa. Fase de relleno arterial. Figure 4. Arteriography of external carotid artery. Arterial bulging phase.
Diagnosis. We should consider an arteriovenous fistula whenever a murmur and thrill appear in a region previously affected by a penetrating wound.

Differential diagnosis. The arteriovenous fistula should be differentiated from:

- Venous malformations: These are soft masses, that are pulsatile and that can be compressed. These lesions grow proportionally with the patient and increase on compressing the jugular vein or with Valsalva's maneuver.

- Lymphatic malformations: These are congenital and many are observed at birth. - Hemangiomas: These are vascular tumors with a growth phase that is marked by endothelial and cellular proliferation and an involution phase.

\section{Case Report}

Female patient, RGP, medical record $N^{\circ} 681458$. The reason given for admittance was an increase in volume of her lower lip.

The condition started at the age of 15 after her lower lip was bitten, which resulted in intense hemorrhaging. As a result of the trauma, the middle and right side of the lip swelled progressively. The area was nontender, purpleblue in color, pulsatile and with a diameter of $3 \mathrm{~cm}$. It was classified as a traumainduced hemangioma and it was treated with betamethasone injections. After 6 doses of betamethasone, the mass was removed using a buccal approach. The histopathologic diagnosis was compatible with a trauma-induced hemangioma.

Two years after being treated the patient presented again, as she had a larger increase in the volume of the lower lip. The area was pulsatile and there was a murmur and thrill (Fig. 1). 
Se aplicaron 4 inyecciones adicionales con triancinolona a intervalos de 3 semanas, notándose una progresiva reducción y fibrosis de la tumoración no constatándose soplo.

A los tres meses de la ligadura de los vasos se practicó la exéresis de la fibrosis de la tumoración labial. El resultado estético final fue aceptable (Figs. 6A y B). En estos momentos la paciente lleva 5 años desde la ultima intervención, no apareciendo recidiva de la lesión.

\section{Discusión}

Las fístulas arteriovenosas pueden ser de origen traumático o congénitas. Las traumáticas suponen el 7,8\% de las lesiones vasculares. ${ }^{5}$ En diversos estudios publicados se encuentra él origen traumático en aproximadamente el $90 \%$ de los casos.5,6

La evolución dependerá fundamentalmente del tamaño de la fístula y su localización pudiendo dar sintomatología local o general. ${ }^{5}$

Los estudios angiográficos y eco gráficos dan el diagnóstico y localización exacta de la fístula. ${ }^{7-11}$

Revisada la bibliografía nacional, solo hemos encontrado un caso, presentado por Felipe Rodríguez, ${ }^{1}$ similar al nuestro producida por una caída de 15 años de evolución.

El fracaso de la primera operación es debido al desconocimiento del aspecto circulatorio de la lesión.

La realización de una arteriografía carotídea nos permitió establecer el diagnostico de la fístula arteriovenosa. La arteriografía, permite conocer el sitio de la comunicación, nos informa de la forma anatómica de la lesión, dato de gran importancia para el tratamiento quirúrgico.

Nuestro caso tuvo una evolución de 7 años. En la actualidad la paciente tiene 9 años de la ultima intervención y no ha presentado recidiva y mantiene un aspecto estético aceptable.

Las fístulas arteriovenosas del labio inferior son pocos frecuentes y su tratamiento quirúrgico constituye un reto a los cirujanos.

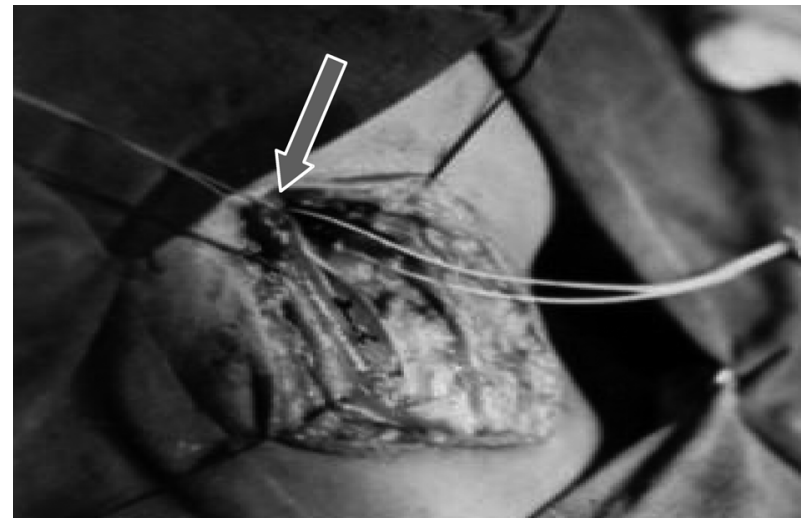

Figura 5. Ligadura de la arteria carótida externa. Figure 5. Ligation of the external carotid artery.
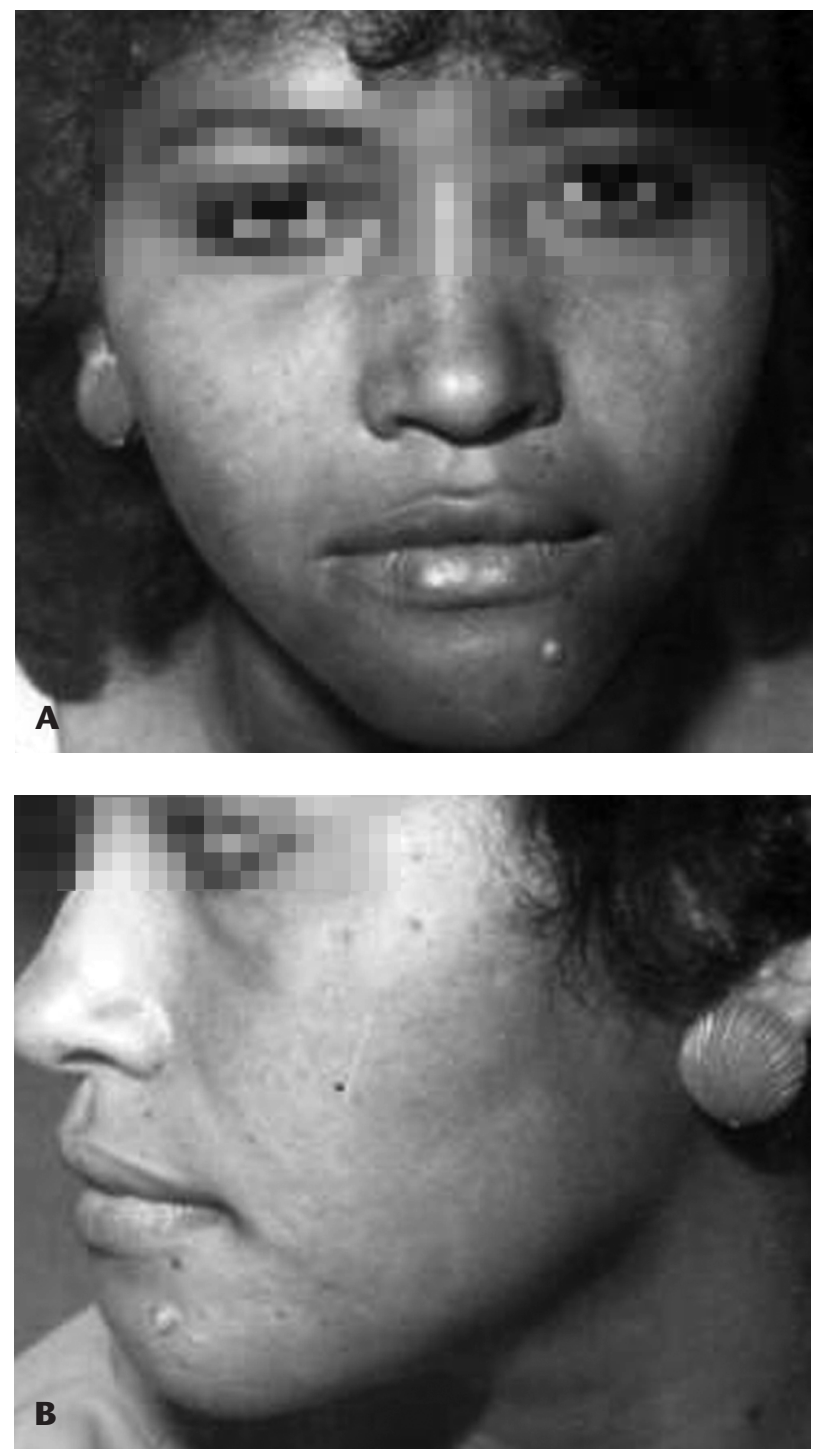

Figura 6. Resultado después de la exéresis del remanente fibroso de la región labial. A) vista de frente. B) Vista lateral.

Figure 6. Result after excision of the remaining fibrous tissue in the lip region. A) Face-on view. B) Side-on view.
The intra-buccal examination revealed a raised vascular pattern in the mucosa of the lower lip (Fig. 2) An ultrasound was requested of the region and dissection was carried out of the right carotid artery for an arteriography, which showed an aneurismatic bulge by the lower labial and chin region (Fig. 3 and 4). The external carotid artery was ligated between the upper thyroid and lingual arteries (Fig. 5). The venous vessels of the aneurysm were ligated by means of a submental incision in order to isolate the cavity from the circulation.

At the end of the surgery, $4 c c$ of betamethasone was injected into the mass and elastic sparadrap was applied. Four additional injections of triamcinolone were given with three week intervals. The progressive reduction together with the fibrosis of the mass was observed, and no murmur was detected.

Three months after the ligation of the vessels, the lip mass was excised. The final aesthetic result was acceptable (Fig. $6 A$ and $B$ ). Five years have elapsed since the surgery and there has been no recurrence of the lesion.

\section{Discussion}

Arteriovenous lesions can have a traumatic or a congenital origin. Traumatic fistulas make up $7.8 \%$ of all vascular lesions. 5 In various studies published a traumatic origin was found in approximately $90 \%$ of cases.5,6 The prognosis depends fundamentally on the size of the fistula and its 


\section{Bibliografía}

1. Felipe Rodríguez F. Fístula arteriovenosa del labio inferior. Rev Cubana Est 1978;15:145-8.

2. Burger T, Tautenhahn J, Grote R, Halloul Z. Diagnosis and management of trauma and iatrogenic induced arteriovenous fistulas in the neck: Vasa. 1999;28: 297300.

3. Sánchez Martínez B, Martínez López C, García Pérez J, Quezada Larios M. Fístula arteriovenosa carótida yugular congénita. Reporte de un caso y revisión de la literatura. Rev Mex Angio 2003;27:66-70.

4. Rance BR, Laws RA, Keeling JH Traumatic arteriovenous fistula of the upper lip. Cutis 2003;62:235-7.

5. Ziyeh S, Schumacher M, Strecker R, Rossler J, Hochmuth A, Klisch J. Head and neck vascular malformations: time-resolved MR projection angiography. Neuroradiology 2003;45:681-6.

6. Cunningham LL Jr, Van Sickels J, Brandt MT. J Angiographic evaluation of the head and neck. Atlas Oral Maxillofac Surg Clin North Am 2003;11:73-86.

7. Vassilyadi $\mathrm{M}$, Jones BV, Ball WS Jr. Identification of an arteriovenous fistula in a child. Case report and review of the literature. Childs Nerv Syst. 2001 Nov;17(11):685-8.

8. Ziyeh S, Schumacher M, Strecker R. Head and neck vascular malformations: time-resolved MR projection angiography. Neuroradiology 2003;45:681-6.

9. Thomas JA, Ware TM, Counselman FL, Surgical treatment of Traumatic fistula of the lower lip. J Emerg Med 2002;22:257-61.

10. Harada J, Mino Y, Hasegawa S, Kubo M, Kuwayama N, Endo S. Traumatic arteriovenous fístula of the lower lip caused by an injury due to penetration by pieces of glass: case report. Oral Maxillofac Surg Clin North Am 2002;30:205-8.

11. Adame $\mathrm{N}$ Jr, Bayless P. arteriovenous fistula in the lip as a result of a bite. J Emerg Med 1998;16:575-8. location. The symptoms can be local or general.5 Angiographic and ultrasound tests will provide the diagnosis and the exact location of the fistula. ${ }^{7-11}$

We revised the national literature but found only one case, presented by Felipe Rodríguez1 that was similar to ours. The case had arisen as a result of a fall and it had a 15-year course.

The failure of the first operation was due to a lack of knowledge as to the circulatory aspect of the lesion. The carotid arteriography permitted establishing a diagnosis of arteriovenous fistula. It permitted knowing the area with the shunt and it provided information on the anatomic shape of the lesion, which was very important information for treating it surgically.

Our case had a clinical course of 7 years. Currently 9 years have passed since the last intervention. There has been no recurrence and the aesthetic result is acceptable.

Arteriovenous fistulas of the lower lip are very infrequent and their surgical treatment is a challenge for surgeons. 